\title{
PENGARUH GREEN PRODUCT TERHADAP MINAT BELI ULANG KONSUMEN MELALUI GREEN ADVERTISING (Studi Terhadap Konsumen Starbucks)
}

\author{
Dicky R. Putra ${ }^{1}$, Yuliana R. Prasetyawati2 ${ }^{2 *}$ \\ ${ }_{1,2}$ Institut Komunikasi dan Bisnis LSPR \\ *Penulis korespondensi; Email: yuliana.rp@1spr.edu
}

\begin{abstract}
Abstrak: Penelitian ini dilakukan untuk menguji pengaruh Green Product Reusable Color Changing Cups terhadap minat beli ulang konsumen Starbucks melalui Green Advertising yang ada di akun Instagram @starbucksindonesia. Metode penelitian yang digunakan adalah metode penelitian deskriptif kuantitatif dan analisis jalur melalui kuesioner yang dibagikan kepada 80 responden yang merupakan followers Instagram @starbucksindonesia yang menggunakan Reusable Color Changing Cups di Sahid Sudirman Center. Hasil penelitian menunjukan bahwa Green Product berpengaruh positif terhadap minat beli ulang yang dimediasi oleh Green Advertising di Instagram @starbucksindonesia. Starbucks harus terus mempertahankan Green Product yang diusung dan ditunjang untuk terus berinovasi dalam menghasilkan produk yang berkualitas dan ramah lingkungan, didukung juga dengan iklan yang menarik konsumen melalui media yang potensial, seperti Instagram.
\end{abstract}

Kata kunci: Green Product, Repurchase Intentio, dan Green Advertising.

\begin{abstract}
The aim of this research is to know and determine the effect of Green Product Reusable Color Changing Cup on Repurchase Intention through @starbucksindonesia Instagram account. The research method used is descriptive research method through quantitative data and path analysis, with 80 respondents who are followers of @ starbucksindonesia on Instagram and Reusable Color Changing Cups users in Sahid Sudirman Centre, Central Jakarta. The results of this research showed that Green Product Reusable Color Changing Cups had a positive impact on Starbucks consumers for repurchase intention through @starbucksindonesia Instagram account. Starbucks Indonesia must maintain its green marketing program and its green product, as well as keep innovating in its ecofriendly products, with increasingly higher quality and supported by advertising campaigns in potential media such as Instagram.
\end{abstract}

Keywords: Green Product, Repurchase Intentio, and Green Advertising.

\section{PENDAHULUAN}

Saat ini minum kopi sudah menjadi bagian dari gaya hidup masyarakat modern. Tren ini pun turut meningkatkan konsumsi kopi di Indonesia. Berkembangnya ragam jenis kopi serta menjamurnya kedai kopi turut menjadi faktor yang membuat kopi lebih dekat dengan masyarakat sehingga menjadi bagian dari gaya hidup masyarakat urban. Tingkat konsumsi kopi di Indonesia terus mengalami peningkatan. Berdasarkan Pusat Data dan Sistem Informasi Pertanian Kementerian Pertanian, konsumsi kopi nasional pada tahun 2016 mencapai sekitar 249.800 ton dan pada tahun 2018, angkanya tumbuh menjadi 314.400 ton. Kedepannya konsumsi kopi di Indonesia diprediksi terus tumbuh rata-rata sebesar 8,22\% per tahunnya. Pada tahun 2021, konsumsi kopi diprediksi mencapai angka 370.000 ton (Apriliyanto, 2020).

Salah satu persoalan dengan meningkatnya konsumsi kopi di masyarakat adalah potensi meningkatnya jumlah sampah plastik dari cup minuman kopi. Starbucks perusahaan internasional yang bergerak dalam bisnis ritel coffee shop menyadari pentingnya perilaku peduli lingkungan untuk menjaga kelestarian bumi. Hal ini mendorong Starbucks Indonesia untuk memproduksi seperti tumbler dan Reusable Cups. Starbucks telah meluncurkan beberapa inisiatif untuk mengurangi dampak lingkungan dari gelas sekali pakai. Tahun 2008, Starbucks meluncurkan gelas plastik baru yang lebih ramah lingkungan dari gelas plastik sebelumnya. Starbucks berkomitmen untuk melakukan lebih banyak dan terus mencari cara baru untuk mengurangi kerusakan lingkungan dari gelas sekali pakai mereka dan kemasan lainnya. (Starbucks, 2020).

Green marketing memiliki prospek yang baik untuk dikembangkan sebagai pilihan strategi pemasaran yang bertanggung jawab sosial. Perusahaan yang menerapkan green marketing tentu memiliki banyak keunggulan dibandingkan strategi konvensional. Keunggulan strategi green marketing akan membuat seseorang mudah percaya dengan suatu produk yang dapat membentuk suatu minat beli dan nantinya akan berdampak pada keputusan pembelian (Agustin, 2015).

Starbucks mengkomunikasikan green product Reusable Color Changing Cup melalui green advertising di akun instagram @starbucksindonesia untuk meningkatkan kesadaran masyarakat dalam menjaga kelestarian lingkungan. Strategi Starbucks dalam 
green advertising dilakukan salah satunya dengan cara membuat iklan yang memuat konten-konten peduli terhadap kelestarian lingkungan, ataupun iklan yang mendorong untuk pembelian green product yang tidak berbahaya bagi lingkungan dan mengarahkan perhatian konsumen kepada konsekuensi positif dari perilaku pembelian.

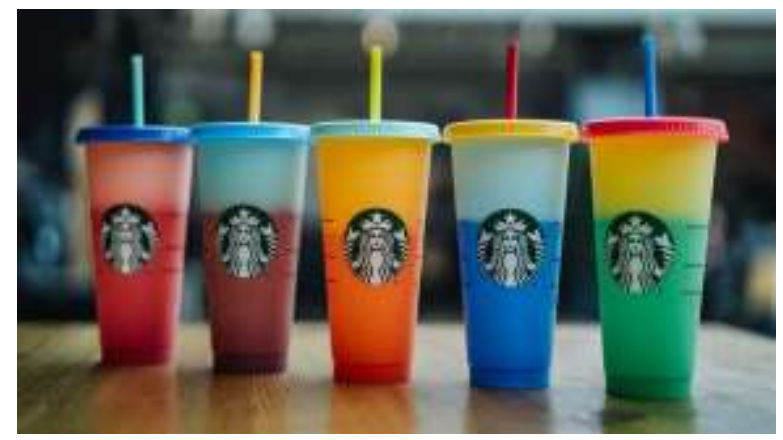

Gambar 1. Reusable Color Changing Cups Sumber: (Starbucks, 2020)

Mengacu pada latar belakang, maka penelitian ini bertujuan untuk menganalisis pengaruh green product reusable color changing cups terhadap minat beli ulang konsumen Starbucks melalui green advertising di Instagram.

\section{TINJAUAN PUSTAKA}

\section{Green Marketing}

American Marketing Association (AMA) mendefinisikan green marketing adalah suatu proses pemasaran produk-produk yang diasumsikan aman terhadap lingkungan (Hawkins and Mothersbaugh, 2016). Green marketing dapat dikatakan tidak sekedar menawarkan produk yang hanya ramah lingkungan, tetapi juga mencakup proses produksi, kemasan, serta aktivitas modifikasi produk. Sementara Wymer and Polonsky (2015) menyatakan bahwa green marketing merupakan seluruh aktivitas yang didesain untuk menghasilkan dan memfasilitasi semua perubahan yang diharapkan dapat memuaskan kebutuhan dan keinginan manusia, dengan dampak minimal pada perusakan lingkungan alam. Konsep green marketing merupakan variasi terminologi dari environmental marketing, ecological marketing, dan sustainable marketing (Prakash, 2015).

\section{Green Product}

Green Product atau produk ramah lingkungan menurut Handayani (2017), merupakan suatu produk yang dirancang dan diproses dengan suatu cara untuk mengurangi efek-efek yang dapat mencermari lingkungan, baik dalam produksi, pendistriusian dan pengonsumsinya. Menurut Rath (2013), green product didefinisikan sebagai produk-produk industri yang diproduksi melalui teknologi ramah lingkungan dan tidak menyebabkan bahaya terhadap lingkungan. Sofhan (2014) menyatakan green product memiliki dimensi yaitu label, kemasan, dan persepsi produk. Label bertujuan memberikan informasi, seperti instruksi penggunaan, kandungan, daftar bahan baku, peringatan penggunaan dan pemeliharaan produk. Kemasan (packaging) dalam suatu produk sudah menjadi perhatian dari green product karena kemasan produk yang ditawarkan merupakan kesempatan dalam meningkatkan kinerja yang berwawasan lingkungan dari produk nyata, tanpa merubah bentuk dari produk inti. Sedangkan persepsi produk (product perception) dari produk yang ramah lingkungan adalah produk organik yang keseluruhan dari produknya dapat didaur ulang, merupakan hasil dari proses produksi bersih dan mempunya masa pakai yang lama sehingga dapat meminimalisasikan jumlah penggunaan produk tersebut.

Karakteristik produk hijau menurut Grant (2015) yaitu: (1) Produk tidak mengandung toxic (racun), (2) Produk lebih tahan lama, (3) Produk menggunakan bahan baku dari bahan daur ulang, (4) Produk tidak menggunakan bahan yang dapat merusak lingkungan, (5) Menggunakan kemasan eco label yang sederhana dan menyediakan produk isi ulang dan (6) Tidak membahayakan bagi kesehatan manusia dan hewan.

\section{Green Advertising}

Menurut Banerjee (2002), green advertising didefinisikan sebagai setiap iklan baik secara eksplisit atau implisit membahas mengenai hubungan antara produk atau jasa dan lingkungan biofisik, mempromosikan green fifestyle atau gaya hidup ramah lingkungan dengan atau tanpa menyoroti produk atau jasa dan menyajikan citra suatu perusahaan mengenai tanggung jawabnya terhadap lingkungan. Green advertising menurut Karna et al. (2016) didefinisikan sebagai periklanan yang tampilannya berwawasan lingkungan. Sabir et al. (2014) menyatakan bahwa konsumen yang memiliki sikap positif pada green advertising akan lebih menyukai dan membeli produk ramah lingkungan. Maka pemasar dapat menggunakan green marketing sebagai taktik yang tepat dalam mempengaruhi perilaku konsumen dalam melakukan pembelian.

\section{Minat Beli Ulang (Repurchase Intention)}

Minat pembelian ulang dipersepsikan sebagai penilaian individu tentang pembelian berulang dari perusahaan atau merek yang sama. Menurut Goh et al. (2016), minat pembelian ulang dapat diartikan sebagai 
kesediaan seorang pembeli untuk membeli kembali merek atau produk yang sama sesuai pengalaman dan harapan. Bahkan, pembelian ulang juga dapat digambarkan sebagai elemen yang paling penting untuk mendorong profitabilitas suatu perusahaan.

Menurut Juniar (2015), minat beli ulang dapat diidentifikasi melalui dimensi-dimensi seperti: 1) Minat transaksional, yaitu kecenderungan seseorang untuk membeli produk, 2) Minat refrensial, yaitu kecenderungan seseorang untuk merefrensikan produk kepada orang lain, 3) Minat preferensial, yaitu minat yang menggambarkan perilaku seseorang yang memiliki preferensi utama pada produk tersebut dan 4) Minat eksploratif, minat ini menggambarkan perilaku seseorang yang selalu mencari informasi mengenai produk yang diminatinya dan mencari informasi untuk mendukung sifat-sifat positif dari produk tersebut.

Green marketing merupakan seluruh aktivitas yang didesain untuk menghasilkan dan memfasilitasi semua perubahan yang diharapkan dapat memuaskan kebutuhan dan keinginan manusia, dengan dampak minimal pada perusakan lingkungan (Polonsky, 2011). Saat ini mulai banyak perusahaan yang mengadopsi strategi green marketing sejalan dengan mulai banyaknya konsumen dan organisasi-organisasi yang peduli akan lingkungan (Nurhadi dan Purnama, 2014).

Konsumen cenderung memilih produk yang sudah dikenal baik atau sudah memiliki citra merek yang baik. Jadi apabila suatu produk memiliki citra diri yang positif dimata konsumen dan diyakini dapat memenuhi kebutuhan dan keinginan konsumen, maka minat membeli suatu produk akan timbul dalam diri konsumen (Pribadi, 2016).

Oleh karena itu, diperoleh kerangka berpikir sebagai berikut:

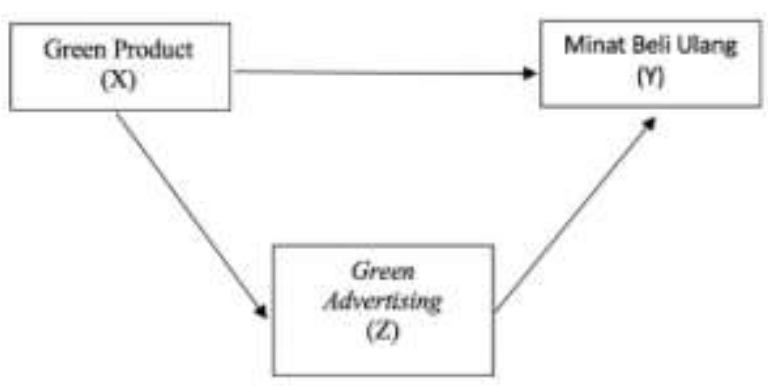

Gambar 2. Kerangka Pemikiran

\section{Hipotesis}

Berdasarkan kerangka berpikir di atas maka disusun hipotesis sebagai berikut:

Ha1: Terdapat pengaruh positif Green Product (X) terhadap Green Advertising (Z).

Ha2: Terdapat pengaruh positif Green Product (X) terhadap Minat Beli Ulang (Y).
Ha3: Terdapat pengaruh positif Green Product (X) terhadap Minat Beli Ulang (Y) melalui Green Advertising (Z).

\section{METODE PENELITIAN}

Penelitian ini menggunakan pendekatan kuantitatif. Metode yang digunakan adalah survei yang menggunakan kuesioner sebagai instrumen dalam mengumpulkan data primer.

Populasi dalam penelitian ini adalah konsumen Starbucks Sahid Sudirman Center Jakarta Pusat yang berjumlah 400 konsumen, jumlah ini didapatkan berdasarkan Average Daily Transaction (ADT) Starbucks Sahid Sudirman Center pada tahun 2020. Dengan batas toleransi kesalahan sebesar 10\%, maka jumlah sampel yang diperlukan sebesar 80 konsumen Starbucks Sahid Sudirman Center Jakarta Pusat. Teknik pengambilan sampel yang digunakan purposive sampling dengan pertimbangan karakteristik anggota sampel penelitian sebagai berikut: 1) Pengguna Reusable Color Changing Cup, 2) Usia 19-36 tahun, 3) Tingkat pendidikan minimal Sekolah Menengah Atas/ sederajat, 4) Konsumen Starbucks Sahid Sudirman Center dan 5) Followers dari akun @starbucksindonesia.

Penelitian ini menggunakan skala Likert dengan 5 penilaian, yaitu Sangat Setuju (5), Setuju (4), Cukup Setuju (3), Tidak Setuju (2), Sangat Tidak Setuju (1). Menurut Irwan (2016) suatu instrumen yang baik harus memenuhi dua syarat yaitu reliabel dan valid, maka dilakukan pre-test untuk menguji validitas dan reliabilitas kuesioner sebelum didistribusikan kepada responden. Metode analisis data yang digunakan dalam penelitian ini adalah analisis jalur.

\section{ANALISIS DAN PEMBAHASAN}

\section{Uji Validitas}

Validitas dimaknai sejauh mana ketepatan dan kecermatan suatu alat ukur dalam melakukan fungsi ukurnya (Azwar, 2015). Suatu instrumen dikatakan valid jika instrumen tersebut mengukur apa yang seharusnya diukur. Uji validitas menggunakan teknik korelasi dan item pertanyaan dinyatakan valid jika antara skor item berkorelasi secara signifikan dengan skor total. Uji validitas pada penelitian ini dilakukan sebelum kuesioner disebarkan dan diberikan kepada sampel pretest sejumlah 30 orang. Nilai $R$ tabel pada signifikansi 0,05 dengan jumlah data $(n)=30$ adalah sebesar 0,326.

Berdasarkan hasil uji validitas diketahui bahwa nilai $\mathrm{R}$ hitung dari semua item pertanyaan variabel Green Product (X), variabel Minat Beli Ulang (Y), dan variabel Green Advertising (Z) lebih besar jika dibandingkan dengan $\mathrm{R}$ tabel 0,326 , maka dapat disimpulkan semua item pertanyaan dinyatakan valid. 


\section{Uji Reliabilitas}

Dasar untuk uji reliabilitas adalah apabila nilai alpha cronbach positif dan lebih besar dari 0,6, maka pertanyaan dinyatakan reliabel. Hasil uji reliabilitas variabel Green Product (X) memiliki nilai alpha cronbach sebesar 0,887 dan lebih besar dari 0,6. Hasil uji reliabilitas variabel Minat beli Ulang (Y) memiliki nilai alpha cronbach sebesar 0,914, artinya lebih besar dari 0,6. Dan hasil uji reliabilitas variabel Green Advertising $(\mathrm{Z})$ memiliki nilai alpha cronbach sebesar 0,918 dan lebih besar dari 0,6. Oleh karena itu, pertanyaan dalam kuesioner dinyatakan reliabel.

\section{Analisis Jalur}

Menurut Sandjojo (2011), analisis jalur adalah sebuah metode yang digunakan untuk menguji kekuatan variabel dengan mengetahui hubungan langsung dan tidak langsung. Kategori pengaruh setiap variabel independen terhadap variabel dependen dalam model adalah sebagai berikut:

1. Jika koefisien jalur bernilai $0,05-0,09$, maka pengaruhnya lemah

2. Jika koefisien jalur bernilai $0,10-0,29$, maka pengaruhnya sedang

3. Jika koefisien jalur bernilai $>0,30$, maka pengaruhnya kuat.

\section{Persamaan Sub Struktural 1}

\section{Pengaruh Green Product (X) terhadap Green Advertising (Z)}

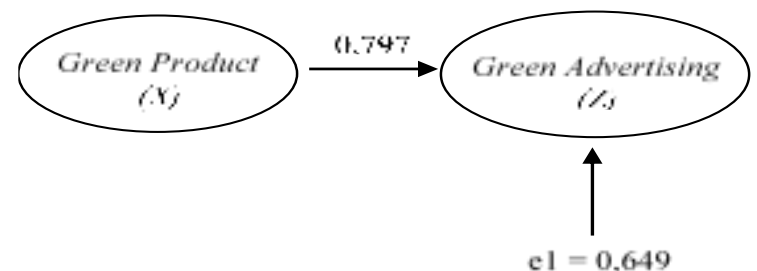

Gambar 3. Model Sub Struktural 1

Sumber: Data Hasil Olahan Peneliti, 2020

Nilai R Square yang dihasilkan adalah sebesar 0,634 . Hal ini menunjukan bahwa pengaruh Green Product (X) terhadap Green Advertising ( $\mathrm{Z}$ ) adalah sebesar $63,4 \%$, sementara sisanya $36,6 \%$ merupakan kontribusi dari variabel lain yang tidak dimasukkan dalam penelitian. Sementara itu untuk nilai e1 dapat dicari dengan rumus e1 $=\sqrt{ }(1-0,634)=0,6049$. Jadi besar koefisien residu yang ikut berkontribusi pada koefisien jalur I yaitu sebesar 0,6049.

Tabel 3. Hasil Uji Signifikansi Analisis

\begin{tabular}{lcl}
\hline \multicolumn{1}{c}{ Variabel } & Sig. Hitung & Hasil \\
\hline X terhadap Z & 0,000 & Signifikan \\
X terhadap Y & 0,034 & Signifikan \\
X terhadap Y melalui Z & 0,000 & Signifikan \\
\hline
\end{tabular}

Sumber: Data Hasil Olahan Peneliti, 2020

Nilai t tabel pada taraf signifikansi 0,05 dengan df $=80-2=78$ adalah 1,66 . Hasil uji t menunjukkan nilai t hitung adalah 11,636 serta memiliki nilai Sig. 0,000. Maka thitung > t tabel $(11,636>1,66)$ dan nilai Sig. < $\alpha(0,000<0,05)$. Dengan demikian Hol ditolak dan Ha1 diterima, maka Green Product (X) berpengaruh secara individu terhadap Green Advertising (Z) dan besarnya $\beta$ (koefisien jalur) sebesar 0,797 .

\section{Persamaan Sub Struktural 2}

\section{Pengaruh Green Product $(X)$ terhadap Minat Beli Ulang (Y) melalui Green Advertising (Z)}

Nilai R Square sebesar 0,599. Hal ini menunjukkan bahwa kontribusi Green Product (X) dan Green Advertising $(\mathrm{Z})$ terhadap Minat Beli Ulang $(\mathrm{Y})$ adalah sebesar 59,9\%, sementara sisanya 40,1\% merupakan kontribusi dari variabel-variabel lain yang tidak dimasukkan dalam penelitian. Sementara itu untuk nilai e2 dapat dicari dengan rumus e $2=\sqrt{ }(1-0,599)=$ 0,6332 . Dengan demikian, besar koefisien residu yang ikut berkontribusi pada sub-struktural 2 yaitu sebesar 0,633 .

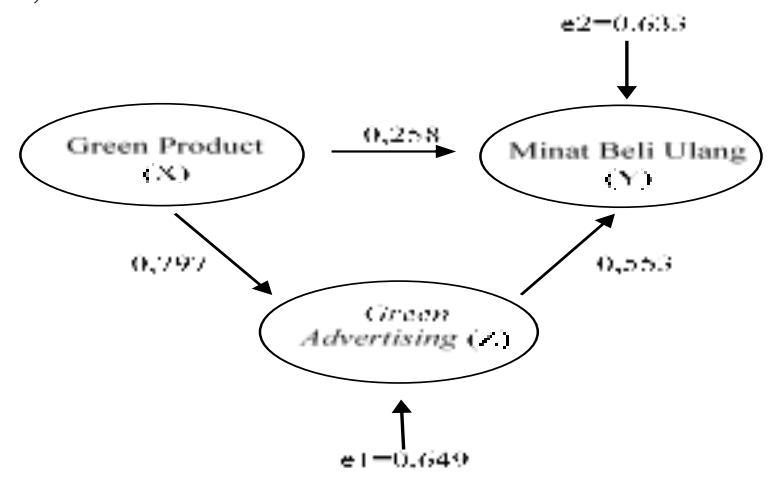

Gambar 4. Model Sub-struktural 2

Sumber: Data Hasil Olahan Peneliti, 2020

Tabel 2. Hasil Pengukuran Pengaruh Langsung dan Tidak Langsung

\begin{tabular}{lcccc}
\hline \multirow{2}{*}{ Variabel } & \multirow{2}{*}{ Koefisien Jalur } & \multicolumn{2}{c}{ Pengaruh } & \multirow{2}{*}{ Total } \\
\cline { 3 - 4 } & 0,797 & Langsung & Tidak Langsung & \\
\hline X terhadap Z & 0,258 & 0,797 & & 0,797 \\
X terhadap Y & 0,553 & 0,258 & $0,797 \times 0,553=0,440$ & 0,698 \\
Z terhadap Y & 0,649 & 0,553 & & 0,553 \\
e1 & 0,633 & 0,649 & & 0,649 \\
e2 & 0,633 & & 0,633 \\
\hline
\end{tabular}

Sumber: Data Hasil Olahan Peneliti, 2020 
Nilai t tabel pada taraf signifikansi 0,05 dengan df $=80-2=78$, adalah 1,66. Nilai t hitung sebesar 2,160 dan memiliki nilai Sig. 0,034. Maka t hitung $>\mathrm{t}$ tabel $(2,160>1,66)$ dan nilai Sig. $<\alpha(0,034<0,05)$. Dengan demikian Ho2 ditolak dan $\mathrm{Ha} 2$ diterima, maka Green Product (X) berpengaruh secara individu terhadap Minat Beli Ulang (Y) dan besarnya $\beta$ (koefisien jalur) sebesar 0,258 ( $\rho z x)$.

Sedangkan pada uji hipotesis pengaruh Green Advertising ( $\mathrm{Z}$ ) terhadap Minat Beli Ulang (Y), dihasilkan nilai t hitung sebesar 4,628 serta memiliki nilai Sig. 0,000. Maka t hitung $>\mathrm{t}$ tabel $(4,628>1,66)$ dan nilai Sig. $<\alpha(0,000<0,05)$. Dengan demikian Ho3 ditolak dan Ha3 diterima, maka Green Advertising $(\mathrm{Z})$ berpengaruh secara individu terhadap Minat Beli Ulang (Y) dan besarnya $\beta$ (koefisien jalur) sebesar $0,553$ ( $\rho z y)$.

$\mathrm{Y}=\rho \mathrm{YX}+\rho \mathrm{YZ}+\mathrm{e} 2$

$Y=0,258 X+0,553 Z+0,633$

Maka, diketahui masing-masing koefisien koefiesien jalur sub-struktural 1 dan 2 adalah sebagai berikut:

1. Koefisien jalur Green Product (X) terhadap Green Advertising $(\mathrm{Z})$ adalah $0,797$.

2. Koefisien jalur Green Product (X) terhadap Minat Beli Ulang (Y) adalah 0,258.

3. Koefisien jalur Green Advertising (Z) terhadap Minat Beli Ulang (Y) adalah 0,553.

\section{Pembahasan}

Penelitian ini menunjukkan terdapat pengaruh yang positif dan sedang antara Green Product (X) terhadap Minat Beli (Y). Artinya inovasi Reusable Color Changing Cups sebagai Green Product yang diluncurkan oleh Starbucks, diterima dengan positif dan sesuai dengan kebutuhan masyarakat yang sudah mulai peduli pada produk-produk yang ramah lingkungan.

Penelitian ini menunjukkan peran penting dari komunikasi pemasaran melalui Green Advertising. Rendahnya kesadaran konsumen untuk menggunakan atau mengonsumsi produk ramah lingkungan karena kurangnya pemahaman akan pentingnya produk ramah lingkungan (Handayani dan Prayogo, 2017). Hal ini dapat diatasi melalui penggunaan green advertising, seperti yang dilakukan oleh Starbucks melalui akun instragramnya. Green Product Reusable Color Changing Cups yang dikomunikasikan melalui Green Advertising di akun instagram @starbucksindonesia, berpengaruh secara positif dan kuat terhadap minat beli ulang konsumen. Hal ini berarti inovasi Reusable Color Changing Cups yang diluncurkan oleh Starbucks, telah menggunakan media komunikasi yang tepat yaitu media sosial Instagram. Penelitian ini juga menunjukkan bahwa pemilihan media yang sesuai dengan target audience menjadi faktor yang penting dalam kesuksesan strategi komunikasi pemasaran.

Hasil penelitian ini juga memperkuat temuan penelitian Gunawan et al. (2014), Agustin (2015), dan Soedargo et al. (2018) yang menyatakan pentingnya green marketing sebagai strategi perusahaan dalam meningkatkan minat beli konsumen.

Alasan mendasar pentingnya green marketing adalah: 1) Peluang atau keunggulan dalam bersaing, yaitu unsur green product dapat menjadi diferensial bagi sebuah produk dan dengan kondisi pasar yang berubah menjadikan green product sebagai sebuah peluang bisnis baru, 2) Menjadi bagian dari Corporate Social Responsibilities dan 3) Green product menjadi senjata dalam bersaing dengan kompetitor karena sulit untuk ditiru.

\section{SIMPULAN DAN SARAN}

Berdasarkan hasil analisis data kuesioner yang disebarkan kepada responden yang merupakan followers@starbucksindonesia, maka dapat disimpulkan bahwa terdapat pengaruh positif dan kuat antara Green Product Reusable Color Changing Cups berpengaruh positif dan kuat terhadap Green Advertising. Sedangkan pengaruh Green Product Reusable Color Changing Cups terhadap Minat Beli adalah positif dan sedang. Hal ini membuktikan bahwa pentingnya peran Green Advertising dalam meningkatkan minat beli ulang Green Product Reusable Color Changing Cups.

Penelitian ini menunjukan pentingnya peranan green marketing sebagai strategi pemasaran yang bertanggung jawab sosial. Seperti yang disampaikan oleh Agustin (2015) bahwa perusahaan yang menerapkan green marketing tentu memiliki banyak keunggulan dibandingkan dengan strategi konvensional. Keunggulan strategi green marketing akan membuat seseorang mudah percaya dengan suatu produk yang dapat membentuk suatu minat beli. Instagram @ starbucksindonesia diharapkan selalu memberikan informasi-informasi bermanfaat, menarik, terkini dan lebih responsif dalam berinteraksi dengan konsumen yang menjadi followers-nya.

Penelitian ini juga menunjukkan pentingnya inovasi produk ramah lingkungan yang dilakukan oleh perusahaan karena sesuai dengan konteks yang relevan dengan masyarakat. Secara khusus, Starbucks dapat terus berinovasi untuk memproduksi green product lainnya, dan terus mengedukasi para followers dan konsumen mengenai pentingnya lingkungan sekitar melalui akun Instagram @ starbucksindonesia sehingga mengurangi dampak terhadap lingkungan dari sampah yang dihasilkan. 


\section{DAFTAR PUSTAKA}

Agustin, D. R. (2015). Pengaruh Green Marketing Terhadap Minat Beli Serta Dampaknya Pada Keputusan Pembelian (Survei Pada Konsumen Non-Member Tupperware Di Kota Malang. Jurnal Administrasi Bisnis, 22(2), 1-10

Apriliyanto, A. D. (2020). Analisis Pengaruh Kualitas Pelayanan, Harga dan Lokasi terhadap Keputusan Pembelian di Kedai Cekopi Mendungan Kartasura (Doctoral dissertation, Universitas Muhammadiyah Surakarta). Electronic Theses and Dissertations, 5.

Banerjee. S.B. (2002). Corporate environmentalism: the construct and its measurement. Journal of Business Research, 55(3), 177-191.

Daft. (2015). Manajemen Pemasaran; Dasar, Konsep dan Strategi. Jakarta: PT. Grafindo Persada.

Goh, S. K., Jiang, N. Hak, M.F.A., \& Tee, P.L. (2016). Determinants of Smartphone Repeat Purchase Intention Among Malaysians: A Moderation Role of Social Influence And A Mediating Effect of Consumer Satisfaction. International Review of Management and Marketing, 6(4), 993-1004.

Grant, J. (2015). The Green Marketing Manifesto. West Sussex, England: John Wiley \& Sons, Ltd.

Gunawan, M., Reinaldo, E., Aprilia, A., \& Hariyanto, A. (2014). Persepsi Konsumen Terhadap Green Marketing Starbucks Surabaya. Jurnal Hospitality dan Manajemen Jasa, 2(2),91 - 109.

Handayani, W., \& Prayogo, R.A. (2017). Green Consumerism: An Eco - Friendly Behavior Form Through The Green Product Consumption and Green Marketing.Sinergi: Jurnal Ilmiah Ilmu Manajemen, 7(2), 25-29.

Hawkins, Del I. \& Mothersbaugh, D. L. (2016). Consumer Behavior: Building Marketing Strategy. 13th, McGraw-Hill International Edition.

Juniar, P. (2015). Pengaruh Kualitas Layanan Terhadap Minat Beli Ulang Melalui Kepuasan Pelanggan di Kartini Restoran Surabaya Plaza Hotel 2015. Perbanas Institutional Repository.

Karna, J., Hansen, E., \& Juslin, H. (2016). Social Responsibility in Environmental Marketing
Planning. European Journal of Marketing, 37, 61-65.

Nurhadi, \& Purnama. (2014). Pengaruh Produk Ramah Lingkungan, Atribut Merek Hijau, Iklan Peduli Lingkungan dan Presepsi Harga Premium terhadap Keputusan Pembelian Produk AMDK. Jurnal Fakultas Ekonomi, 1-9.

Polonsky, M. J. (2011). Transformative Green Marketing: Impediments and Opportunities, Journal of Business Research, (64), 1311-1319.

Pribadi, S. R. (2016). Strategi Pemasaran Produk Tabungan Simpanan Pelajar (SIMPEL) Di Bank BRI Syariah KC Purwokerto. Doctoral Dissertation IAIN Purwokerto.

Rath, R. C. (2013). An Impact of Green Marketing On Practices of Supply Chain Management In Asia: Emerging Economic Opportunities And Challenges. International Journal of Supply Chain Management, 2(1).

Sabir, S., Khurshid, \& Hafeez. (2014). Influence of Factors in Green Advertising upon Purchase Intentions- A Study of Pakistani University Students. International Review of Management and Business Research, 3(4), 2131 - 2138.

Sandjojo. N (2011). Metode Analisis Jalur (Path Analysis) dan Aplikasinya, Cetakan Pertama. Jakarta, Penerbit Pustaka Sinar Harapan.

Soedargo, N. P., Wisana, K., \& Kristanti, M. (2018). Pengaruh Green Marketing Terhadap Sikap Konsumen dan Minat Beli Ulang di Green Hotel di Indonesia. Jurnal Hospitality dan Manajemen Jasa, 6(2); 197 - 205.

Sofhan, Y. N. (2014). Pengaruh Green Product Terhadap Keputusan Pembelian (Studi Pada Produk Air Conditioner Panasonic Inverter Econavi Di Jakarta Pusat). Universitas Telkom, 4.

Starbucks. (2020, June 22). Greener Cups and Packaging. Diakses dari: Retrieved from starbucks. com: https://www.starbucks.com/responsibility/ environment/recycling.

Wymer, W., \& Polonsky, M. (2015). The Limitations and Potentialities of Green Marketing. Journal of Nonprofit \& Public Sector Marketing, 27(3), 239-262. 